Article

\title{
Manure and Paper Mill Sludge Application Effects on Potato Yield, Nitrogen Efficiency and Disease Incidence
}

\author{
Adrien N'Dayegamiye ${ }^{1, *}$, Judith Nyiraneza ${ }^{2}$, Marcel Giroux ${ }^{1}$, Michèle Grenier ${ }^{1}$ and \\ Anne Drapeau ${ }^{1}$ \\ 1 Research and Development Institute for the Agri-Environment (IRDA), 2700 Einstein, \\ Complexe scientifique, D.1.110, Sainte-Foy, QC, G1P 3W8, Canada; \\ E-Mails: marietgiroux@hotmail.com (M.G.); michele.grenier@irda.qc.ca (M.G.); \\ anne.drapeau@irda.qc.ca (A.D.) \\ 2 Agriculture and Agri-Food Canada, Crops and Livestock Research Centre, 440 University Avenue, \\ Charlottetown, PE, C1A 4N6, Canada; E-Mail: judith.nyiraneza@agr.gc.ca \\ * Author to whom correspondence should be addressed; E-Mail: adrien.ndaye@irda.qc.ca; \\ Tel.: +1-418-643-2380; Fax: +1-418-644-6855.
}

Received: 19 October 2012; in revised form: 18 December 2012 / Accepted: 8 January 2013 / Published: 15 January 2013

\begin{abstract}
Appropriate organic amendment management is essential in potato production to increase soil productivity and potato (Solanum tuberosum L.) quality. The objectives of this two-year field study (2004-2005) were to evaluate the effects of organic amendment applications with or without mineral $\mathrm{N}$ fertilizer addition on potato yield, $\mathrm{N}$ uptake, $\mathrm{N}$ use efficiency (NUE), and on disease incidence. The experimental design was a split-plot, which included nine treatments with four different organic amendments applied in fall 2003 or in spring 2004 at a rate of $40 \mathrm{Mg} \mathrm{ha}^{-1}$ (wet basis) and an unamended control in main plots, and $\mathrm{N}$ fertilizer rates $\left(0\right.$ and $\left.90 \mathrm{~kg} \mathrm{~N} \mathrm{ha}^{-1}\right)$ in sub-plots. Organic amendments consisted of fresh cattle manure (FCM), composted cattle manure (CCM), paper mill sludge with $\mathrm{C} / \mathrm{N}$ ratio $<15\left(\mathrm{PMS}_{1}\right)$ and paper mill sludge with $\mathrm{C} / \mathrm{N}>15\left(\mathrm{PMS}_{2}\right)$ applied alone $\left(0 \mathrm{~kg} \mathrm{~N} \mathrm{ha}^{-1}\right)$ or supplemented with mineral fertilizer at a rate $90 \mathrm{~kg} \mathrm{~N} \mathrm{ha}^{-1}$. The $\mathrm{N}$ fertilizer rate in the unamended control consisted of 0 and $150 \mathrm{~kg} \mathrm{~N} \mathrm{ha}{ }^{-1}$. No organic amendments were applied in 2005 to evaluate residual effects. Fall and spring applications of FCM, CCM and PMS alone significantly increased $\mathrm{N}$ uptake and potato marketable yields by 2.5 to $16.4 \mathrm{Mg} \mathrm{ha}^{-1}$, compared to the unfertilized control. Combining organic amendments with $\mathrm{N}$ fertilizer at $90 \mathrm{~kg} \mathrm{~N}^{-1}$ increased potato yields, $\mathrm{N}$ uptake, and specific gravity, which were comparable to those obtained in mineral $\mathrm{N}$ fertilizer
\end{abstract}


treatments (150 kg N ha $\left.{ }^{-1}\right)$. Residual effects of organic amendments alone had no significant effects on potato yields or on $\mathrm{N}$ uptake compared to the unfertilized control. Potato NUE for FCM, CCM and PMS ranged from $6 \%$ to $25 \%$ in the first year and from $2 \%$ to $8 \%$ in the residual year. The NUE values were higher for PMS with lower $\mathrm{C} / \mathrm{N}$ ratio compared to FCM and CCM. This study did not show any difference between organic amendment applied in spring or fall on potato yield and quality. It was also demonstrated that mineral $\mathrm{N}$ fertilizer needed to be combined with organic amendments to sustain potato yield and $\mathrm{N}$ nutrition. This study showed that appropriate organic amendment management could increase potato yield and quality and reduce $\mathrm{N}$ fertilizer requirement.

Keywords: manure; paper mill sludge; potato; $\mathrm{N}$ use efficiency; fertilizer $\mathrm{N}$ equivalency; specific gravity; common scab; black scurf
Abbreviations
FCM: fresh dairy cattle manure
CCM: composted dairy cattle manure
MF: mineral $\mathrm{N}$ fertilizer
NUE: nitrogen use efficiency
FNE: fertilizer nitrogen equivalency
$\mathrm{PMS}_{1}$ : paper mills sludge with a $\mathrm{C} / \mathrm{N}$ ratio $<15$
$\mathrm{PMS}_{2}$ : paper mill sludge with a $\mathrm{C} / \mathrm{N}$ ratio $>15$

\section{Introduction}

Regular application of organic amendments can sustain soil $\mathrm{N}$ fertility and increase potato yields. Dairy cattle manure and paper mill sludge application improved soil physical and biological properties and increased corn yields and $\mathrm{N}$ availability [1]. Canali et al. [2] reported that farmyard manure and compost applications sustained potato yield. These authors showed that green manures and organic amendments might provide a valid alternative to the conventional mineral $\mathrm{N}$ fertilizer mitigating potential environmental risks due to $\mathrm{N}$ leaching. Thus, potato crop presents a great potential for receiving animal manures and paper mill sludges. Approximately a million tons of paper mill sludges and more than 30 million tons of animal manures are applied annually on the soils of the province of Quebec, Canada [3].

Better use of organic amendments requires however knowledge of their $\mathrm{N}$ use efficiency as it is important that $\mathrm{N}$ released from animal manures or organic amendments meet potato $\mathrm{N}$ requirements. Lower $\mathrm{N}$ supply or efficiency can lead to nutrient deficiency and poor growth and yield, respectively, whereas excessive $\mathrm{N}$ supply from organic amendments may induce excessive vegetative growth and low yields and quality $[4,5]$. A better $\mathrm{N}$ optimization from organic amendments can be achieved with knowledge of the organic material nitrogen release rates [3,6,7] and additional mineral $\mathrm{N}$ fertilizer $\mathrm{N}$ additions may be needed to satisfy crop needs. The $\mathrm{N}$ availability or $\mathrm{N}$ use efficiency of manure or 
other organic amendments is lower than that of mineral $\mathrm{N}$ fertilizer $[3,6]$. Nitrogen from organic amendments is mostly in organic form and must be mineralized to become available to crops. The $\mathrm{N}$ availability is affected by their chemical composition that is characterized by total $\mathrm{N}$ and $\mathrm{C} / \mathrm{N}$ ratio [3,8,9]. Chadwick et al. [9] established that $40 \%$ of the variation in the $\mathrm{N}$ mineralization rate of manure was explained by the $\mathrm{C} / \mathrm{N}$ ratio. Fast $\mathrm{N}$ mineralization and availability is expected for organic fertilizers with low $\mathrm{C} / \mathrm{N}$ ratio $(<15)[3,10]$. The PMS with $\mathrm{C} / \mathrm{N}$ ratios below 15 decompose quickly in the soil during the first year of the application and $\mathrm{N}$ released is readily available to the crop [3].

Nitrogen use efficiency from organic amendments also depends on the crop species. Long-season crops such as potatoes and grain corn will use more mineralized $\mathrm{N}$ from organic materials compared with short period crops such as cereals $[3,8,11]$. The application timing also influences the nitrogen use efficiency [12,13]. Although fall application of organic materials is likely to be associated with economic and logistic advantages including time saving, it is also at higher risk of $\mathrm{N}$ losses associated with leaching or denitrification that occurs during fall and early spring $[11,13]$. On the other hand, spring application of organic amendments can increase soil compaction because of wet soil conditions [14]. Several studies investigated advantages of fall versus spring application of manure and organic materials on corn yield. Solid swine manure fall application increased corn yield compared to spring application $[12,13,15,16]$. Hansen et al. [13] reported that fall and spring application of solid dairy cattle manure gave similar barley (Hordeum vulgare L.) yield and $\mathrm{N}$ uptake.

The main challenge in managing organic amendments for potato nutrition is to match $\mathrm{N}$ release with the crop $\mathrm{N}$ demand. The potato crop requires much $\mathrm{N}$ in the early season, between 65 and 75 days after planting [17]. The $\mathrm{N}$ availability from organic amendments may not be concomitant with the crop $\mathrm{N}$ demand period. Therefore, to meet crop $\mathrm{N}$ needs, organic amendments application has to be supplemented with $\mathrm{N}$ fertilizer although nitrogen surplus can occur when highly mineralizable organic materials are applied at high rates and are combined with mineral $\mathrm{N}$ fertilizer. This may promote excessive vine growth, resulting in delayed tuber bulking and maturation, low specific gravity and higher levels of reducing sugars in tubers.

The use of organic amendments in potato production can also influence potato disease incidence [18]. The role of fresh or composted organic materials in reducing soil-borne diseases for potato, corn and bean has been reported by Darby et al. [19], Olanya et al. [18] and Hoitink and Fahy [20]. It was hypothesized that organic amendments application may stimulate soil microbial activity and reduce the impact of soil-borne pathogens on crops, as a result of greater competition [18-21]. Other studies showed that applying farmyard manure and liquid swine manure to potato reduced scab and black scurf severity [22,23].

Improved organic amendment management requires knowledge of their $\mathrm{N}$ use efficiency to maintain potato quality, as excessive $\mathrm{N}$ availability may reduce potato quality and increase disease incidence. The objectives of this two-year study were to evaluate the effects of solid dairy cattle manures, paper mill sludge application and mineral $\mathrm{N}$ fertilizer addition on potato yield and quality, and $\mathrm{N}$ use efficiency in the year of application and in the subsequent year. We also determined the effect of these organic amendments on common scab and black scurf incidences. 


\section{Materials and Methods}

\subsection{Field Site and Organic Materials}

The experiment was carried out in 2004 and 2005 in a field of the Research and Development Institute for the Agri-Environment (IRDA) located in Deschambault, near Québec City, Canada $\left(46^{\circ} 34^{\prime} \mathrm{N}, 71^{\circ} 13^{\prime} \mathrm{W}\right)$. The soil is a Batiscan densic podzol (sandy over clayey, mixed, nonacid, frigid, Aeric Humaquet) which corresponds to orthic podzol for FAO classification). The particle-size distribution of the A horizon $(0-20 \mathrm{~cm})$ was $820 \mathrm{~g}$ sand kg $^{-1}, 50 \mathrm{~g} \mathrm{silt} \mathrm{kg}^{-1}$, and $130 \mathrm{~g}$ clay kg $\mathrm{kg}^{-1}$. The

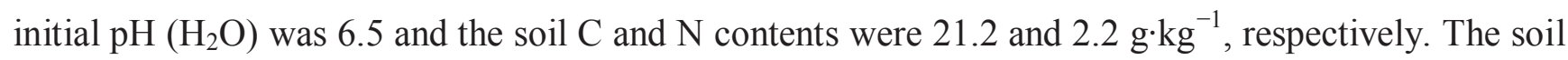
available $\mathrm{P}$ and $\mathrm{K}$ contents were 381 and $274 \mathrm{mg} \cdot \mathrm{kg}^{-1}$, respectively.

Fresh dairy cattle manure (FCM) and dairy cattle manure compost (CCM) were collected from a Quebec Ministry of Agriculture experimental dairy farm station, and paper mill sludges were obtained from the Abitibi-Bowater paper mill located at Donnacona, near Québec, Canada. The FCM and CCM contained on average $303 \mathrm{~g} \mathrm{~kg}^{-1}$ dry matter, $412 \mathrm{~g} \cdot \mathrm{kg}^{-1} \mathrm{C}, 19 \mathrm{~g} \cdot \mathrm{kg}^{-1} \mathrm{~N}, 24 \mathrm{~g} \cdot \mathrm{kg}^{-1} \mathrm{P}$, and $69 \mathrm{~g} \cdot \mathrm{kg}^{-1} \mathrm{~K}$ (Table 1). The paper mill sludges (PMS) used contained $194 \mathrm{~g} \cdot \mathrm{kg}^{-1}$ dry matter, $443 \mathrm{~g} \cdot \mathrm{kg}^{-1} \mathrm{C}$, $34 \mathrm{~g} \cdot \mathrm{kg}^{-1} \mathrm{~N}, 10 \mathrm{~g} \cdot \mathrm{kg}^{-1} \mathrm{P}$ and $59 \mathrm{~g} \cdot \mathrm{kg}^{-1} \mathrm{~K}$. The $\mathrm{C} / \mathrm{N}$ ratio ranged from 8.0 to 30 depending on the organic materials. The PMS applied contained less P and K compared to dairy cattle FCM or CCM.

Table 1. Physical and chemical properties * of organic amendments applied in fall 2003 and in spring 2004.

\begin{tabular}{|c|c|c|c|c|c|c|c|c|}
\hline $\begin{array}{c}\text { Application } \\
\text { time }\end{array}$ & $\begin{array}{c}\text { Organic } \\
\text { amendments }\end{array}$ & $\begin{array}{c}\text { DM } \\
{\mathrm{g} \cdot \mathrm{kg}^{-1}}^{-1}\end{array}$ & $\begin{array}{c}\text { Organic C } \\
\mathbf{g} \cdot \mathrm{kg}^{-1}\end{array}$ & $\begin{array}{c}\text { Total N } \\
{\mathrm{g} \cdot \mathrm{kg}^{-1}}\end{array}$ & $\mathrm{~N} \mathrm{ha}^{-1} \mathrm{~kg}^{\dagger}$ & $\begin{array}{c}\mathrm{P} \\
\mathrm{mg} \cdot \mathrm{kg}^{-1} \\
\end{array}$ & $\begin{array}{c}\mathrm{K} \\
\mathrm{mg} \cdot \mathrm{kg}^{-1}\end{array}$ & $\mathrm{C} / \mathrm{N}$ \\
\hline \multirow{4}{*}{ Fall 2003} & $\mathrm{PMS}_{1}$ & 144 & 440 & 55.0 & 317 & 13.7 & 6.2 & 8 \\
\hline & $\mathrm{PMS}_{2}$ & 229 & 460 & 20.9 & 191 & 8.9 & 4.5 & 22 \\
\hline & $\mathrm{FCM}$ & 386 & 399 & 13.6 & 210 & 30.6 & 73.8 & 30 \\
\hline & $\mathrm{CCM}$ & 377 & 402 & 22.5 & 339 & 43.8 & 104.2 & 18 \\
\hline \multirow{4}{*}{ Spring 2004} & $\mathrm{PMS}_{1}$ & 151 & 432 & 37.9 & 229 & 8.6 & 3.8 & 11 \\
\hline & $\mathrm{PMS}_{2}$ & 251 & 439 & 21.3 & 214 & 7.9 & 4.1 & 20 \\
\hline & $\mathrm{FCM}$ & 261 & 447 & 22.0 & 230 & 13.2 & 50.4 & 20 \\
\hline & $\mathrm{CCM}$ & 189 & 400 & 20.2 & 153 & 8.3 & 46.3 & 20 \\
\hline
\end{tabular}

FCM: Fresh cattle manure; CCM: composted cattle manure; $\mathrm{PMS}_{1}$ : paper mill sludge with $\mathrm{C} / \mathrm{N}<15$; $\mathrm{PMS}_{2}$, paper mill sludge with $\mathrm{C} / \mathrm{N}$ of $>15$; DM, dry matter; * Organic $\mathrm{C}$ and nutrient contents are referred on dry matter basis; ${ }^{\dagger}$ Total $\mathrm{N}$ applied with $40 \mathrm{Mg} \mathrm{ha}^{-1}$.

\subsection{Experimental Design}

The experimental design was a split-plot with organic amendments in main plots and mineral $\mathrm{N}$ fertilizer rates in sub-plots ( 0 and $\left.90 \mathrm{~kg} \mathrm{~N} \mathrm{ha}^{-1}\right)$. The study included nine treatments in main plots with four different organic amendments applied in fall 2003 or in spring 2004 at a rate of $40 \mathrm{Mg} \mathrm{ha}^{-1}$ (wet basis) and an unamended control. Treatments with organic amendments consisted of fresh cattle manure (FCM), composted cattle manure $(\mathrm{CCM})$, paper mill sludge with $\mathrm{C} / \mathrm{N}$ ratio $<15\left(\mathrm{PMS}_{1}\right)$ and paper mill sludge with $\mathrm{C} / \mathrm{N}>15\left(\mathrm{PMS}_{2}\right)$ applied alone $\left(0 \mathrm{~kg} \mathrm{~N} \mathrm{ha}^{-1}\right)$ or supplemented with mineral fertilizer at a rate of $90 \mathrm{~kg} \mathrm{~N} \mathrm{ha}{ }^{-1}$. The $\mathrm{N}$ fertilizer rate in the unamended control consisted of 0 and 
$150 \mathrm{~kg} \mathrm{~N} \mathrm{ha}^{-1}$. Mineral $\mathrm{N}$ fertilizer rate recommended in eastern Canada is $150 \mathrm{~kg} \mathrm{~N}^{-1}$ for potato in fertilizer management guidelines. Nitrogen fertilizer supplemented to organic amendment was reduced at $90 \mathrm{~kg} \mathrm{~N}^{-1}$ to avoid excessive $\mathrm{N}$, which may induce pest incidence and reduce potato yield quality (specific gravity). Results obtained for corn in the same climatic conditions showed that nitrogen release for manure and paper mill sludges was about $25 \%$ which represents 60 to $90 \mathrm{~kg} \mathrm{~N} \mathrm{ha}{ }^{-1}$ depending on organic material types [3]. Corn and potato have a long growth period and present similar N needs for growth.

The plot size was $6 \mathrm{~m}$ wide and $12 \mathrm{~m}$ long. No additional organic amendments were applied in 2005 to evaluate residual effects. The organic amendments were surface applied to different plots with a manure spreader on 23 October 2003 and 20 May 2004 and immediately rototilled into the soil into a depth of about $10 \mathrm{~cm}$. Calcium ammonium nitrate (27-0-0) was the source of inorganic $\mathrm{N}$ fertilizer, which was applied at $90 \mathrm{~kg}$ and $150 \mathrm{~kg} \mathrm{~N} \mathrm{ha}^{-1}$ in amended and unamended treatments, respectively. Prior to planting, each plot received a base application of $75 \mathrm{~kg} \mathrm{P}_{2} \mathrm{O}_{5} \mathrm{ha}^{-1}$ as superphosphate, and $75 \mathrm{~kg} \mathrm{~K}_{2} \mathrm{O} \mathrm{ha}^{-1}$ as muriate of potassium based on soil analysis. Potato tubers (cv. Chieftain) were planted in the last week of May 2004 and 2005 with a $35 \mathrm{~cm}$ in-row spacing and distance of $91.5 \mathrm{~cm}$ between rows, resulting in a crop density of 45,000 plants $\mathrm{ha}^{-1}$. Pesticide management was as recommended in Quebec for potato crop.

\subsection{Analytical Methods}

Potato tubers were hand-harvested from two 12-m row sections of a middle row from each plot. The harvested tubers were graded in the following categories: Large $(7.9-11.4 \mathrm{~cm})$ and Canada No.1 $(5.1-7.9 \mathrm{~cm})$. The small $(<5.1 \mathrm{~cm})$ and deformed tubers were also recorded. A representative 4-kg sample of tubers from each plot was used for determination of tuber dry matter, specific gravity, $\mathrm{N}$ content and diseases. Six representative tubers from each plot were quartered along the long axis, and one quarter from each tuber was sliced into strips of $1 \mathrm{~cm} \times 1 \mathrm{~cm}$, weighed, oven dried at $55^{\circ} \mathrm{C}$, and re-weighed to determine dry matter content. The tuber samples were ground to pass $0.15 \mathrm{~mm}$ for the total $\mathrm{N}$ determination.

Potato specific gravity was determined from three samples per plot by using the weight in air/weight in water method. Randomly selected tubers from each plot were rinsed with water and rated for common scab (Streptomyces scabiei) and black scurf (Rhizoctonia solani Kuhn). Disease severity was determined using a rating scale of zero to six based on the percentage of tuber surface covered with scab or black scurf lesions, i.e., $0,0 \% ; 1,1 \%-5 \% ; 2,6 \%-15 \% ; 3,16 \%-25 \%, 4,26 \%-35 \%$; $5,36 \%-60 \%$ and $6,61 \%-100 \%$ [22]. Severity of common scab and black scurf was measured as an index calculated by counting the number of tubers $(n=50)$ falling in classes 0 to 6 . The number in each class was multiplied by the class number and summed.

For organic amendments, dry matter content was analyzed from weight loss by oven drying at $70{ }^{\circ} \mathrm{C}$; $\mathrm{pH}$ was determined in $0.01 \mathrm{M} \mathrm{CaCl}_{2}$ in $1: 2(\mathrm{w} / \mathrm{v})$ organic material: solution ratio, total $\mathrm{C}$ by loss on ignition; total $\mathrm{N}$ by dry combustion (CNS-1000, LECO Corporation, St-Joseph, MI, USA); total P and $\mathrm{K}$ by wet digestion in $\mathrm{H}_{2} \mathrm{SO}_{4}-\mathrm{H}_{2} \mathrm{O}_{2}$ [24]. The $\mathrm{P}$ concentration in the extracts was determined colorimetrically (Hitachi U-1000, Tokyo, Japan) using the molybdate reaction, whereas the $\mathrm{K}$ concentration was determined by flame absorption spectroscopy (Perkin-Elmer 503, Überlingen, 
Germany). Soil total $\mathrm{C}$ was determined by the Walkley-Black method [25] and $\mathrm{N}$ by Kjeldahl digestion [26]. Total $\mathrm{C}$ content was considered to represent organic $\mathrm{C}$ because this soil does not contain carbonates. Extractable P and K were determined in a Mehlich III solution [27]. Total N levels were measured using an Automated Technicon Autoanalyzer (Model AAII, Technicon Instruments, Tarytown, NY, USA) and mineral elements (P, K) using an inductively coupled plasma optical emission spectrometer (Perkin Elmer 4300 DV, Boston, MA, USA; Model AAII, Technicon Instruments, Tarytown, NY, USA). Particle size analysis was performed on air-dried soils by the pipette method after the destruction of organic matter with $\mathrm{H}_{2} \mathrm{O}_{2}$ and dispersion with sodium hexametaphosphate [28]. Soil pH was measured in 1:1 soil:water solution.

\subsection{Calculations}

Nitrogen use efficiency (NUE) reflects the amount of applied nitrogen recovered by tubers. Data obtained on potato $\mathrm{N}$ uptake in 2004 and 2005 were used to determine apparent $\mathrm{N}$ use efficiency for mineral $\mathrm{N}$ fertilizer $\left(150 \mathrm{~kg} \mathrm{~N} \mathrm{ha}^{-1}\right)$ and organic $\mathrm{N}$ amendments. The apparent NUE was calculated following the method used by Zvomuya et al. [29]:

$$
\mathrm{NUE}=(\text { Ntreat }- \text { Ncontrol }) \times 100 / \mathrm{N} \text { applied }
$$

where Ntreat represents the amount of nitrogen accumulated in the tubers for a given fertilizer treatment (organic amendment or mineral $\mathrm{N}$ fertilizer); Ncontrol is the amount of $\mathrm{N}$ removed by tubers in the unfertilized control plots $\left(0 \mathrm{~kg} \mathrm{~N}^{-1}\right) ; \mathrm{N}$ applied is the total $\mathrm{N}$ applied with mineral or organic amendments.

Nitrogen efficiency for applied organic amendments refers to fertilizer $\mathrm{N}$ equivalency. The fertilizer $\mathrm{N}$ equivalency (FNE) was estimated as follow:

$$
\mathrm{NUE}_{\mathrm{OA}} \times 100 / \mathrm{NUE}_{\mathrm{NF}}
$$

where $\mathrm{NUE}_{\mathrm{OA}}$ is the apparent $\mathrm{N}$ use efficiency in the treatments with organic amendment application and $\mathrm{NUE}_{\mathrm{NF}}$ in the treatment with $\mathrm{N}$ fertilizer application.

\subsection{Statistical Analysis}

To assess the effects of treatments on the response variables, a normal mixed model was fitted to the data using the PROC MIXED procedure of SAS [30]. The fixed effects were the treatments of organic amendments, the $\mathrm{N}$ fertilizer level and the interaction organic amendment $\times \mathrm{N}$ fertilizer. The random effects were the blocks, the whole-plot error and the residual error. The random effects were assumed to be independent and normally distributed with mean zero and constant variance $\sigma^{2}$ bor the blocks, $\sigma^{2}{ }_{w}$ for the whole-plots and $\sigma^{2}$ for the residual errors. The $F$-tests for fixed effects of the analysis of variance table were considered. 


\section{Results and Discussion}

\subsection{Rainfall and Temperature at Studied Site in 2004 and 2005}

Total monthly rainfall and average monthly temperature were different in both years (Figure 1). Year 2004 had more rain early in the growing season (May and June) than 2005 and the reversed was observed toward the end of the growing season where year 2005 showed higher rainfall than 2004. On the other hand, year 2005 was warmer than 2004 during the whole growing season.

Figure 1. Monthly precipitation and average monthly temperature at studied site.
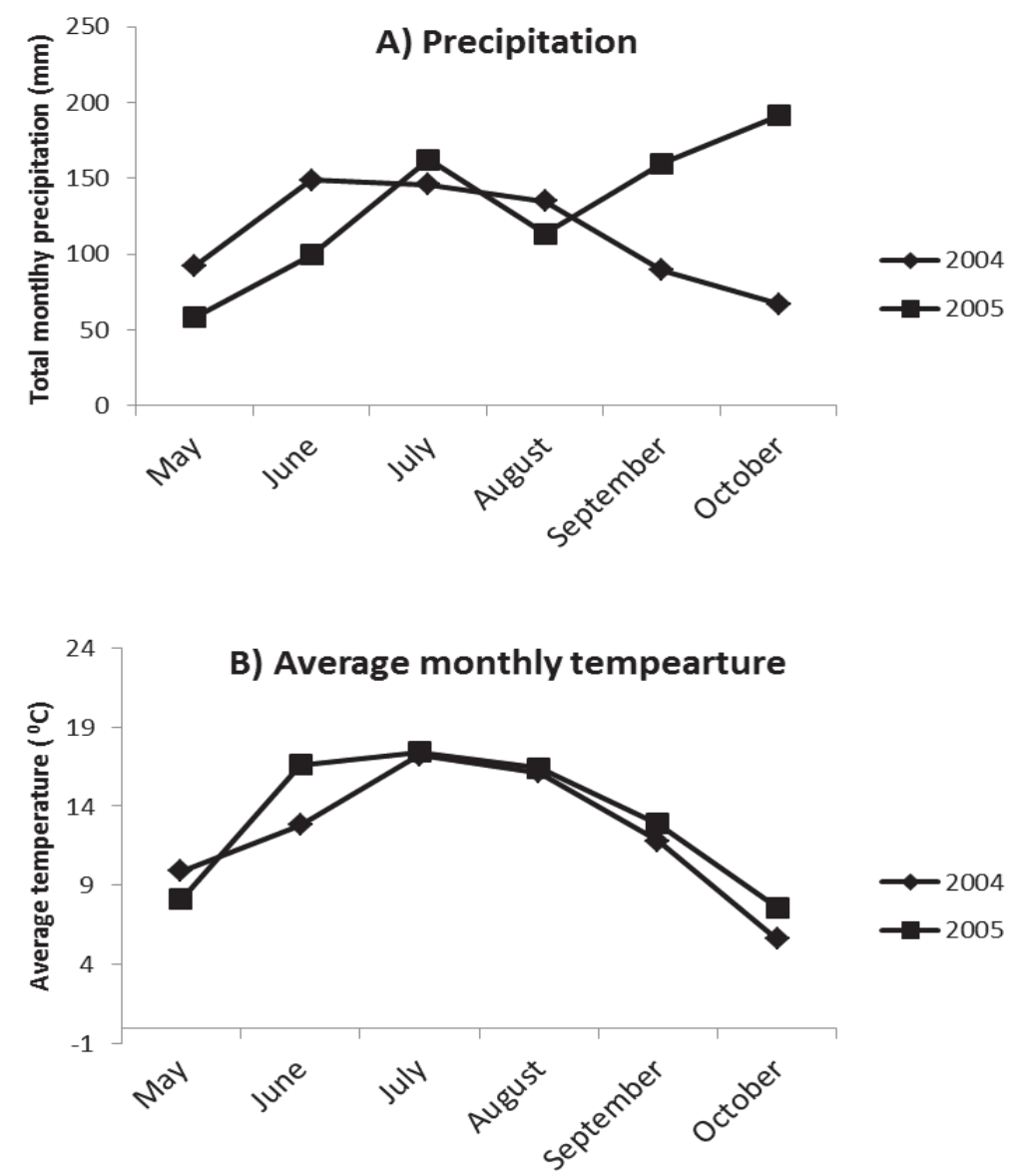

Data were from St. Camille meteorological station, Quebec $\left(46^{\circ} 29^{\prime} 00,000^{\prime \prime N} ; 70^{\circ} 13^{\prime} 00,000^{\prime \prime} \mathrm{O}\right)$.

\subsection{Potato Yields, N Uptake and Specific Gravity}

In 2004, organic amendment application significantly increased the total and marketable yield, and there was a significant interaction between organic amendments and $\mathrm{N}$ fertilizer $(P<0.001)$ (Table 2 and Figure 2A,C). Organic amendments applied alone increased total and marketable yields by 3.6 to $17.2 \mathrm{Mg} \mathrm{ha}^{-1}$ and by 2.5 to $16.4 \mathrm{Mg} \mathrm{ha}^{-1}$ respectively, compared with the unamended and unfertilized control. Potato yields were increased by $11.3 \%$ to $54.3 \%$ when organic amendments were combined with $\mathrm{N}$ fertilizer, compared with organic amendments applied alone. Potato yields with mineral $\mathrm{N}$ fertilized plots $\left(150 \mathrm{~kg} \mathrm{~N} \mathrm{ha}^{-1}\right)$ were comparable or greater than those obtained with organic amendments supplemented with $90 \mathrm{~kg} \mathrm{~N}$ fertilizer ha ${ }^{-1}$ (Figure 2A,C). When applied alone, fresh and 
composted dairy cattle manure (FCM and CCM) gave lower potato yields than $\mathrm{PMS}_{1}$ and $\mathrm{PMS}_{2}$ but the opposite was observed when they were supplemented with $\mathrm{N}$ fertilizer (Figure 2A,C). This is probably due to excessive $\mathrm{N}$ from applied PMS and $\mathrm{N}$ fertilizer, which can lead to excessive vegetative growth and low yields as also was reported by Ojala et al. [4] and Porter et al. [5] for nitrogen fertilizer. In fact, the $\mathrm{N}$ content in dairy cattle manure was lower than that of $\mathrm{PMS}_{1}$ (Table 1).

Table 2. Analysis of variance of the effects of organic amendment application with or without reduced $\mathrm{N}$ fertilizer on potato yield, $\mathrm{N}$ uptake and disease incidence ( $P$ values).

\begin{tabular}{cccccccc}
\hline Treatments & Total yield & $\begin{array}{c}\text { Marketable } \\
\text { yield }\end{array}$ & DM & $\begin{array}{c}\text { Specific } \\
\text { gravity }\end{array}$ & N uptake & $\begin{array}{c}\text { Common } \\
\text { scab }\end{array}$ & $\begin{array}{c}\text { Black } \\
\text { scurf }\end{array}$ \\
\hline $\begin{array}{c}\text { Organic } \\
\text { amendment }\end{array}$ & 0.0164 & 0.0142 & 0.8883 & 0.0183 & 0.0462 & 0.1348 & 0.2092 \\
$\begin{array}{c}\text { N fertilizer } \\
\text { Organic } \times\end{array}$ & $<0.0001$ & $<0.0001$ & 0.1036 & 0.0430 & $<0.0001$ & 0.0136 & 0.0192 \\
N fertilizer & $<0.0001$ & $<0.0001$ & 0.1468 & 0.0847 & $<0.0001$ & 0.4538 & 0.7936 \\
\hline \multicolumn{1}{c}{$\begin{array}{c}\text { Organic } \\
\text { amendment }\end{array}$} & 0.3529 & 0.3610 & 0.9816 & 0.1398 & 0.5187 & 0.3321 & 0.2154 \\
$\begin{array}{c}\text { N fertilizer } \\
\text { Organic } \times\end{array}$ & $<0.0001$ & $<0.0001$ & 0.8030 & 0.0009 & $<0.0001$ & 0.8714 & 0.1261 \\
N fertilizer & 0.4845 & 0.5935 & 0.2665 & 0.4256 & 0.2991 & 0.1322 & 0.4453 \\
\hline
\end{tabular}

In 2005, we determined the residual effect of organic amendments on potato yield, and no effect of organic amendments was observed. (Table 2, Figure 2B,D) while the effect of $\mathrm{N}$ fertilizer application was highly significant $(P<0.0001)$. Residual effects of organic amendments applied alone were negligible as potato yields obtained from these treatments were comparable to those in the unamended and unfertilized control (Figure 2B,D). Paper mill sludges alone gave yields comparable to those of unamended and fertilized treatment $\left(150 \mathrm{~kg} \mathrm{~N} \mathrm{ha}^{-1}\right)$ in 2004 but were comparable to those in unamended and unfertilized control $\left(0 \mathrm{~kg} \mathrm{~N} \mathrm{ha}^{-1}\right)$ in 2005. The low $\mathrm{C} / \mathrm{N}$ ratio associated with PMS implies rapid $\mathrm{N}$ decomposition and negligible residual $\mathrm{N}$ effects in the subsequent years as reported previously by N'Dayegamiye [3]. These results suggest that for organic amendments with low $\mathrm{C} / \mathrm{N}$ ratio $(\mathrm{C} / \mathrm{N}<30)$ the application of $\mathrm{N}$ fertilizer is required in the residual year to sustain crop $\mathrm{N}$ needs.

Potato $\mathrm{N}$ uptake varied from 98 to $179 \mathrm{~kg} \mathrm{~N}^{-1}$ in 2004 and from 85 to $214 \mathrm{~kg} \mathrm{~N}^{-1}$ in 2005 (Figure 3A,B). Organic amendments and mineral fertilizer significantly increased potato $\mathrm{N}$ uptake in 2004 ( $P=0.0462$ and $P \leq 0.0001$, respectively) compared with the unamended and unfertilized treatments (Table 2). The interaction of organic amendment and $\mathrm{N}$ fertilizer was also significant on potato $\mathrm{N}$ uptake. During the two years of the study, the combination of organic amendment with mineral $\mathrm{N}$ increased $\mathrm{N}$ uptake by an average of $105 \%$ compared with organic amendment applied alone. As for potato yields, synergic effects of organic amendments with mineral $\mathrm{N}$ fertilizer on $\mathrm{N}$ uptake were important $(P<0.0001)$. These results show that additional mineral $\mathrm{N}$ fertilizer is necessary to satisfy crop $\mathrm{N}$ nutrition following organic amendments application. Most of the $\mathrm{N}$ in $\mathrm{CM}$ or PMS is in organic form and needs to be mineralized to be available to the crop. 
No difference in potato yield and $\mathrm{N}$ uptake was found between fall or spring manure and paper mill sludge application (Figure 3A,B). Our results are similar to those obtained by Hansen et al. [13], Thomsen [16] and MacLeod et al. [31] where fall or spring application of dairy cattle manure gave similar barley and corn response.

In 2004, the specific gravity of tubers in plots amended with organic amendments ranged from 1.070 to 1.073 (Figure 3C), and was significantly increased by organic amendment and mineral fertilizer application (Table 2). The interaction of organic amendment and $\mathrm{N}$ fertilizer was not significant. In general, higher values of tuber specific gravity were observed in 2005 than in 2004 (Figure 3C versus Figure 3D). Optimum moisture availability as tubers approach maturity can increase specific gravity and our results could probably be explained by the fact that precipitation and temperature were higher in 2005 during September and October than in 2004 (Figure 1A).

Figure 2. Effects of mineral $\mathrm{N}$ fertilization and organic amendments with or without $\mathrm{N}$ fertilizer (N) on total (A, B) and marketable yield (C, D) in 2004 and 2005, respectively.
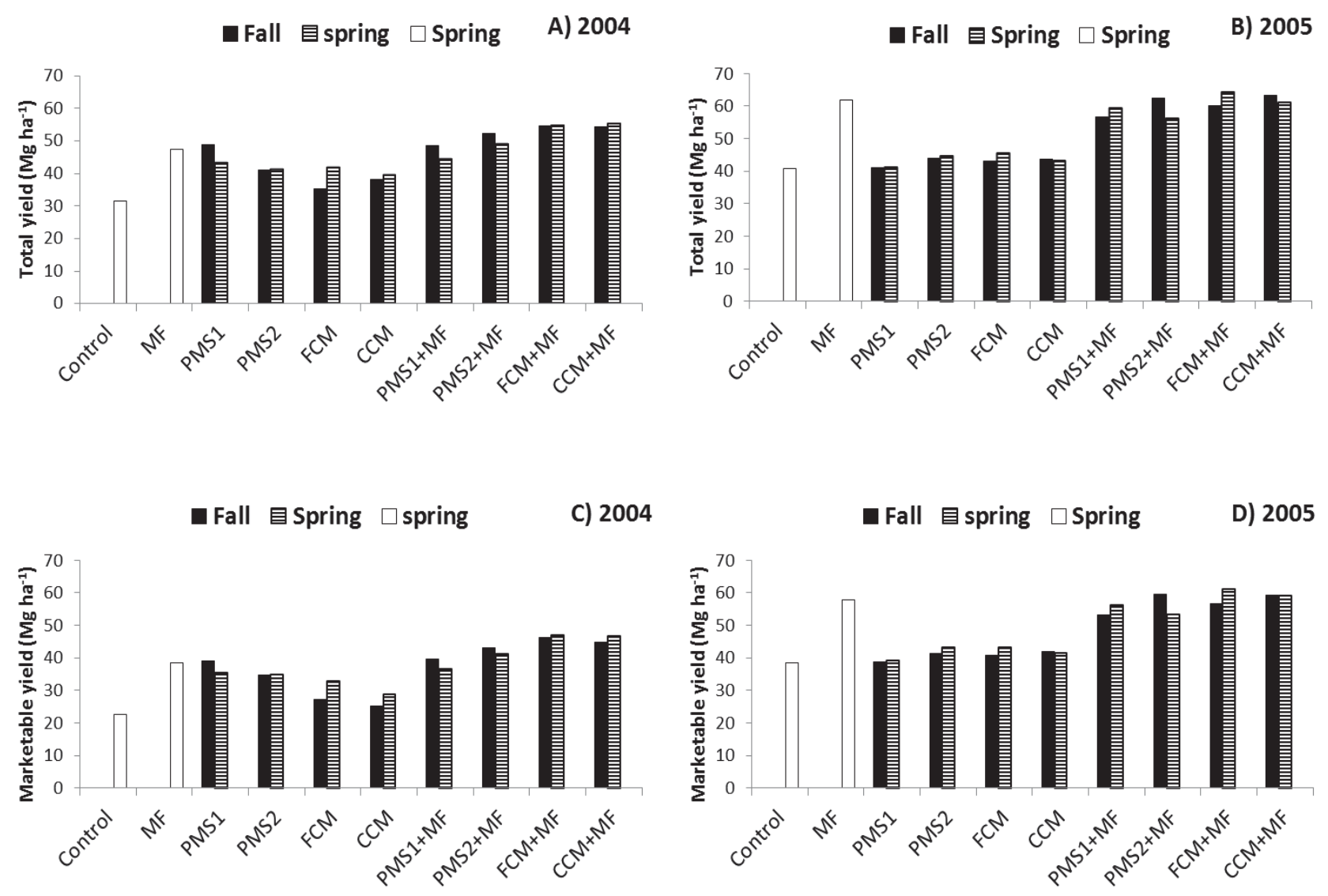

Control: non $\mathrm{N}$ fertilizer was applied; MF: mineral fertilizer applied at $150 \mathrm{~kg} \mathrm{~N} \mathrm{ha}{ }^{-1}$; $\mathrm{PMS}_{1}$ : paper mill sludge with $\mathrm{C} / \mathrm{N}<15 ; \mathrm{PMS}_{2}$ : mixed paper mill sludge with $\mathrm{C} / \mathrm{N}$ of $20 ; \mathrm{FCM}$ : fresh dairy cattle manure; CCM: composted dairy cattle manure; $\mathrm{PMS}_{1}+\mathrm{FM}, \mathrm{PMS}_{2}+\mathrm{MF}, \mathrm{FCM}+\mathrm{MF}$, $\mathrm{CCM}+\mathrm{MF}$ refer to $\mathrm{PMS}_{1}, \mathrm{PMS}_{2}, \mathrm{FCM}$, and CCM supplemented with mineral fertilizer at a rate of $90 \mathrm{~kg} \mathrm{~N} \mathrm{ha}{ }^{-1}$. 
Figure 3. Effects of mineral $\mathrm{N}$ fertilization and organic amendments with or without $\mathrm{N}$ fertilizer (N) on total and N uptake (A, B) and specific gravity (C, D) in 2004 and 2005.

@ Fall 目Spring $\square$ Spring

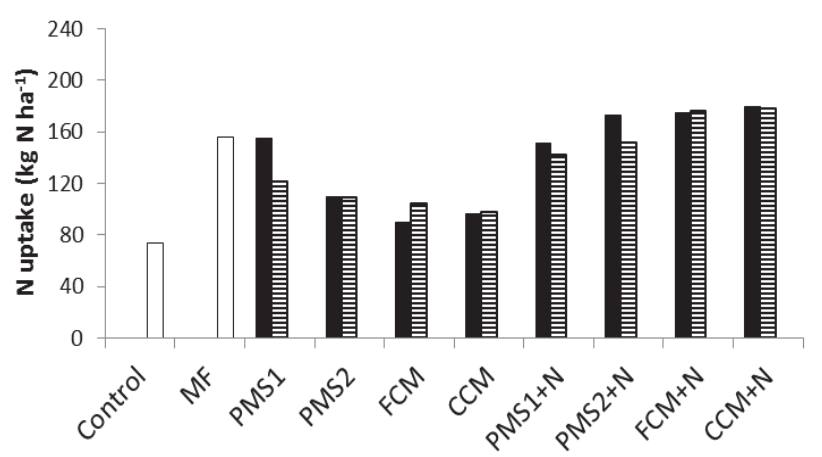

— Fall 目 Spring $\square$ spring

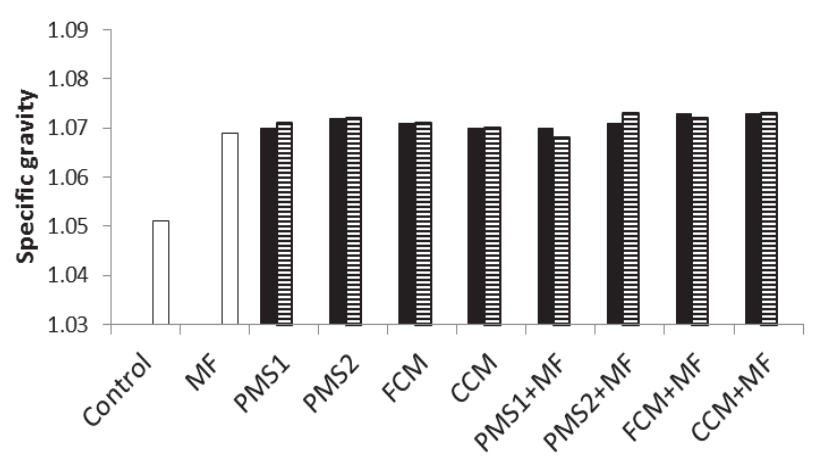

—Fall 目Spring $\square$ Spring

B) 2005

Control: non $\mathrm{N}$ fertilizer was applied; MF: mineral fertilizer applied at $150 \mathrm{~kg} \mathrm{~N}$ ha ${ }^{-1}$; $\mathrm{PMS}_{1}$ : paper mill sludge with $\mathrm{C} / \mathrm{N}<15$; $\mathrm{PMS}_{2}$ : mixed paper mill sludge with $\mathrm{C} / \mathrm{N}$ of $20 ; \mathrm{FCM}$ : fresh dairy cattle manure; CCM: composted dairy cattle manure; $\mathrm{PMS}_{1}+\mathrm{FM}, \mathrm{PMS}_{2}+\mathrm{MF}, \mathrm{FCM}+\mathrm{MF}$, $\mathrm{CCM}+\mathrm{MF}$ refer to $\mathrm{PMS}_{1}, \mathrm{PMS}_{2}, \mathrm{FCM}$, and CCM supplemented with mineral fertilizer at a rate of $90 \mathrm{~kg} \mathrm{~N} \mathrm{ha}^{-1}$.

\subsection{Nitrogen Use Efficiency (NUE) and Fertilizer N Equivalency (FNE)}

The NUE of the organic amendment treatments ranged from $13 \%$ to $25 \%$ and was lower compared to mineral fertilized treatment (54\%) (Table 3). Among organic amendments, $\mathrm{PMS}_{1}$ exhibited the highest NUE (20\% and 25\%) while FCM and CCM had the lowest NUE. The $\mathrm{PMS}_{2}$ had intermediate NUE values, which were higher than those of FCM and CCM. The relatively low NUE of fresh and composted manures (Table 3) are probably related to their stable and less available organic N, as demonstrated also by potato lower yield and $\mathrm{N}$ uptake. The bedding material used in dairy farm was sawdust, which produces less decomposable N. 
Table 3. Potato $\mathrm{N}$ use efficiency and fertilizer $\mathrm{N}$ equivalency in the first year of organic amendment application (2004).

\begin{tabular}{cccccc}
\hline $\begin{array}{c}\text { Application } \\
\text { time }\end{array}$ & $\begin{array}{c}\text { Organic } \\
\text { amendment }\end{array}$ & $\begin{array}{c}\text { Total } \mathbf{~ i n p u t s} \\
\left(\mathbf{k g ~ h a}^{-\mathbf{1}}\right)\end{array}$ & $\begin{array}{c}\mathbf{N} \text { uptake } \\
\left(\mathbf{k g ~ h a}^{-1}\right)\end{array}$ & $\begin{array}{c}\text { NUE } \\
(\mathbf{\%})\end{array}$ & $\begin{array}{c}\text { FNE } \\
\mathbf{( \% )}\end{array}$ \\
\hline \multirow{3}{*}{ Fall 2003 } & $\mathrm{PMS}_{1}$ & 317 & 155 & 25 & 46 \\
& $\mathrm{PMS}_{2}$ & 191 & 109 & 18 & 33 \\
& $\mathrm{FCM}$ & 210 & 90 & 8 & 15 \\
& $\mathrm{CCM}$ & 339 & 96 & 6 & 10 \\
\hline \multirow{3}{*}{ Spring 2004 } & $\mathrm{PMS}_{1}$ & 229 & 121 & 20 & 37 \\
& $\mathrm{PMS}_{2}$ & 214 & 108 & 16 & 30 \\
& $\mathrm{FCM}$ & 230 & 104 & 13 & 24 \\
N fertilizer & $\mathrm{CCM}$ & 153 & 97 & 15 & 28 \\
Control & & 150 & 155 & 54 & 100.0 \\
\hline
\end{tabular}

FCM: Fresh cattle manure; CCM: composted cattle manure; NUE: Apparent N use efficiency; FNE: fertilizer $\mathrm{N}$ equivalency; $\mathrm{PMS}_{1}$ : paper mill sludges with $\mathrm{C} / \mathrm{N}<15$; $\mathrm{PMS}_{2}$ : paper mill sludges with $\mathrm{C} / \mathrm{N}$ of 20 .

The FNE in the first year of application followed this order: $\mathrm{PMS}_{1}>\mathrm{PMS}_{2}>\mathrm{FCM}$ and CCM independently of application time (Table 3). Generally, the PMS had the highest FNE with average values of $41 \%$ and $31 \%$ for $\mathrm{PMS}_{1}$ and $\mathrm{PMS}_{2}$, respectively. These results corroborate findings of N'Dayegamiye [3] and Vagstad et al. [32] who reported net $\mathrm{N}$ mineralization and high $\mathrm{N}$ availability of PMS in the first year of application. The FNE of FCM and CCM were lower than that of PSM. As reported above for NUE, the higher FNE of PMS is associated with low $\mathrm{C} / \mathrm{N}$ ratio. This result is in line with the finding of Douglas et al. [11] in an experiment with barley where FNE was negatively related to the $\mathrm{C} / \mathrm{N}$ ratio of the organic amendments. In the residual year, values of NUE varied from $2 \%$ to $8 \%$ (Table 4). Values of FNE in the residual year (2005) ranged from 3\% to 13\% (Table 4) compared with values ranging from $10 \%$ to $46 \%$ in 2004 (Table 3). Similarly to NUE, the FNE values were higher for PMS than for FCM and CCM in the residual year.

Table 4. Potato $\mathrm{N}$ use efficiency and fertilizer $\mathrm{N}$ equivalency in the residual year of organic amendments application (2005).

\begin{tabular}{|c|c|c|c|c|c|}
\hline Application time & $\begin{array}{c}\text { Organic } \\
\text { amendment }\end{array}$ & $\begin{array}{l}\text { Total } N \text { inputs } \\
\left(\mathrm{kg} \mathrm{ha}^{-1}\right)\end{array}$ & $\begin{array}{c}\text { Residual year } \\
\text { N uptake }\left(\mathrm{kg} \mathrm{ha}^{-1}\right)\end{array}$ & $\begin{array}{l}\text { NUE } \\
(\%)\end{array}$ & $\begin{array}{l}\text { FNE } \\
(\%)\end{array}$ \\
\hline \multirow{4}{*}{ Fall 2003} & $\mathrm{PMS}_{1}$ & 317 & 97 & 4 & 6 \\
\hline & $\mathrm{PMS}_{2}$ & 191 & 98 & 6 & 10 \\
\hline & $\mathrm{FCM}$ & 210 & 102 & 8 & 13 \\
\hline & $\mathrm{CCM}$ & 339 & 91 & 2 & 3 \\
\hline \multirow{4}{*}{ Spring 2004} & $\mathrm{PMS}_{1}$ & 229 & 101 & 7 & 11 \\
\hline & $\mathrm{PMS}_{2}$ & 214 & 101 & 8 & 13 \\
\hline & $\mathrm{FCM}$ & 230 & 100 & 6 & 10 \\
\hline & $\mathrm{CCM}$ & 153 & 88 & 2 & 3 \\
\hline $\mathrm{N}$ fertilizer & & 150 & 183 & 60 & 100.0 \\
\hline Control & & 0 & 85 & $\ldots$ & \\
\hline
\end{tabular}

FCM: Fresh cattle manure; CCM: composted cattle manure; NUE: Apparent N use efficiency; FNE: fertilizer $\mathrm{N}$ equivalency; $\mathrm{PMS}_{1}$ : paper mill sludges with $\mathrm{C} / \mathrm{N}<15 ; \mathrm{PMS}_{2}$, paper mill sludges with $\mathrm{C} / \mathrm{N}$ of 20 . 
Data obtained in this study generally show that FCM and CCM gave lower NUE compared to mineral $\mathrm{N}$ fertilizer that is readily soluble as has also been observed by Sommer [33] and Gutser et al. [34]. Based on the total NUE obtained in the first and residual years, $\mathrm{N}$ recovered by the potato crop from applied PMS in fall or spring varied from $27 \%$ to $29 \%$, which represented 62 to $82 \mathrm{~kg} \mathrm{~N} \mathrm{ha}^{-1}$. Nitrogen recovered from FCM and CCM was much lower than that of PMS. Our results evidence that it is efficient to supplement $\mathrm{N}$ fertilizer to organic amendments to meet crop $\mathrm{N}$ needs and to maintain a high marketable potato yield.

\subsection{Incidence of Common Scab and Black Scurf}

The levels of common scab ranged from $0.25 \%$ to $2 \%$ in 2004 and from $22.0 \%$ to $33.8 \%$ in 2005 (Figure 4A,B). The analysis of variance showed that organic amendment application in 2004 had no significant effect on common scab incidence $(P=0.1348)$ in the first year of application (Table 2$)$. In contrast, common scab incidence was significantly increased by mineral $\mathrm{N}$ fertilizer application in 2004 (Table 2). In 2005, the effect of organic amendment and mineral fertilizer on common scab incidence was not significant. As for common scab, organic amendments application had no effect on black scurf levels in 2004, but the mineral N fertilization effect was significant (Table 2). In 2005, symptoms of black scurf were lower than in 2004 (Figure 4C versus Figure 4D) and opposite trends were observed with common scab, where the scab incidence was higher in 2005 than in 2004. Scab disease severity is impacted by several factors such as soil type and organic amendments, crop rotation, soil moisture and soil acidity. Soil moisture levels close to field capacity in the weeks following tuberization inhibit scab infection (Lapwood and Hering [35]; Lapwood et al. [36]). Black scurf is also controlled by environmental conditions. Shoot development is fast when the planting is done into warmer soils and is unlikely to be affected by black scurf. The difference observed between the two years on common scab and on black scurf is probably related to different environmental conditions in both years. The year 2005 seemed to be warmer than 2004 (Figure 1B) which may have inhibited black scurf incidence, and 2004 seemed to be moister during tuber formation than 2005 and these conditions may have decreased scab incidence.

Results of this study showed that organic amendments did not increase scab and black scurf incidence compared to mineral $\mathrm{N}$ fertilizer. In a study on corn, N'Dayegamiye [1] demonstrated that paper mill sludges and dairy cattle manure significantly increased soil microbial and enzymatic activity. Organic amendments probably increased soil microbial population and activity and reduced potato diseases by competition as was hypothesized by Darby et al. [19]. 
Figure 4. Effects of mineral $\mathrm{N}$ fertilization and organic amendments with or without supplemental $\mathrm{N}$ fertilizer $(\mathrm{N})$ on common scab (A, B) and black scurf (C, D) in 2004 and 2005 .
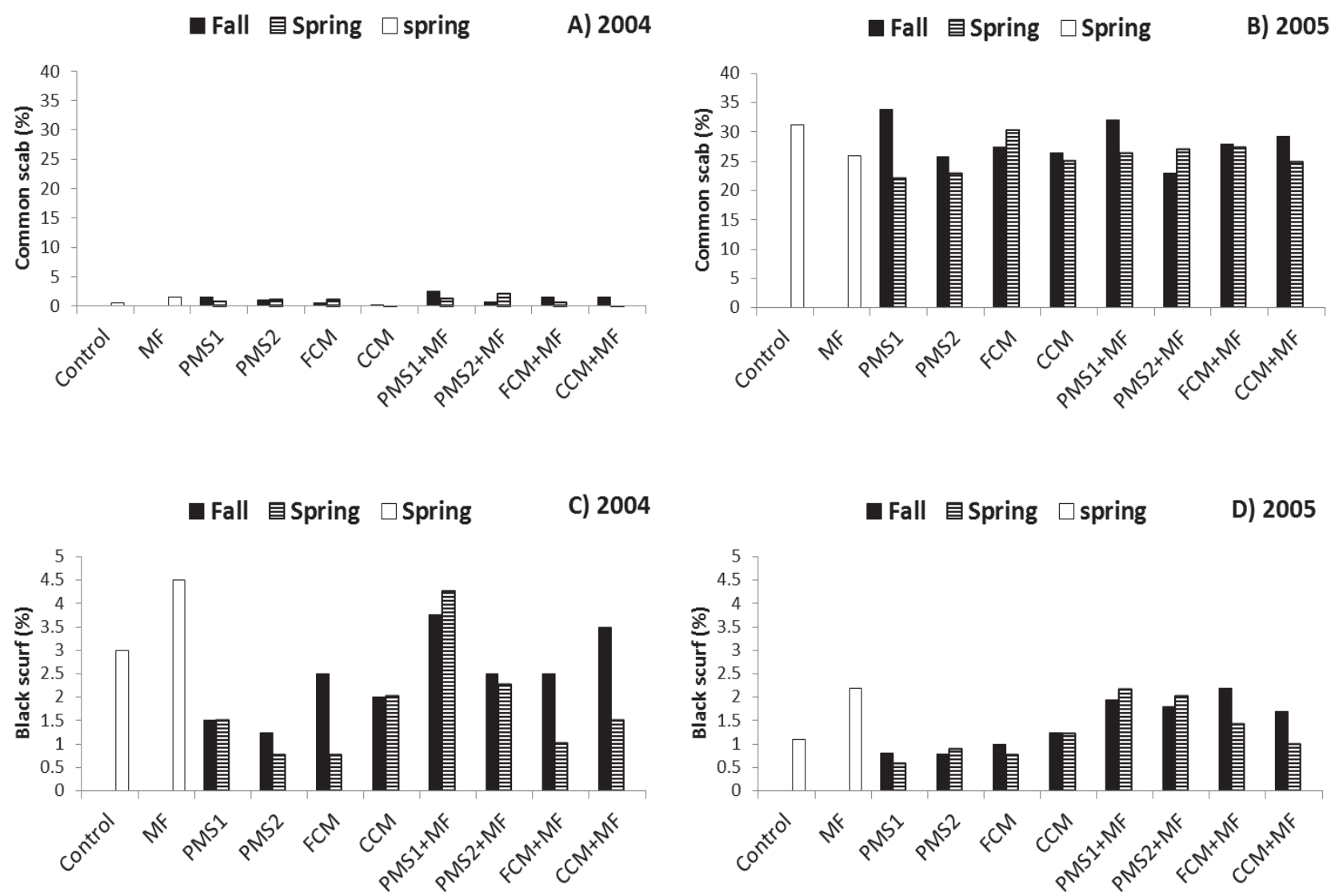

Control: non $\mathrm{N}$ fertilizer was applied; MF: mineral fertilizer applied at $150 \mathrm{~kg} \mathrm{~N}$ ha ${ }^{-1}$; $\mathrm{PMS}_{1}$ : paper mill sludge with $\mathrm{C} / \mathrm{N}<15 ; \mathrm{PMS}_{2}$ : mixed paper mill sludge with $\mathrm{C} / \mathrm{N}$ of 20 ; FCM: fresh dairy cattle manure; CCM: composted dairy cattle manure; $\mathrm{PMS}_{1}+\mathrm{FM}, \mathrm{PMS}_{2}+\mathrm{MF}, \mathrm{FCM}+\mathrm{MF}$, $\mathrm{CCM}+\mathrm{MF}$ refer to $\mathrm{PMS}_{1}, \mathrm{PMS}_{2}, \mathrm{FCM}$, and CCM supplemented with mineral fertilizer at a rate of $90 \mathrm{~kg} \mathrm{~N}^{-1}$.

\section{Conclusions}

The application of solid dairy cattle manures and paper mill sludges increased marketable potato yield by 2.5 to $16.4 \mathrm{Mg} \mathrm{ha}^{-1}$, compared to the unamended and unfertilized soil. The highest potato yield and $\mathrm{N}$ uptake were obtained where organic amendments were supplemented with mineral $\mathrm{N}$ fertilizer $\left(90 \mathrm{~kg} \mathrm{~N} \mathrm{ha}^{-1}\right)$. In 2004 and 2005, the NUE and FNE were higher with PMS than FCM and CCM. Based on the total NUE obtained in the first and residual years, $\mathrm{N}$ recovered by the potato crop from applied PMS in fall or spring varied from $27 \%$ to $29 \%$, which corresponded to 62 to $82 \mathrm{~kg} \mathrm{~N} \mathrm{ha}{ }^{-1}$. Potato yield and $\mathrm{N}$ uptake were increased when organic amendments were supplied with mineral $\mathrm{N}$ fertilizer at $90 \mathrm{~kg} \mathrm{~N} \mathrm{ha}{ }^{-1}$. This suggests that supplemental $\mathrm{N}$ fertilizer is necessary even for organic amendments with high available $\mathrm{N}$ to meet potato $\mathrm{N}$ needs and to increase marketable yield. The application of organic amendments did not increase potato common scab and black scurf incidences compared with mineral $\mathrm{N}$ fertilizer treatment. This study shows that appropriate organic amendment management can increase potato yield and quality and reduce $\mathrm{N}$ fertilizer requirement. 


\section{Acknowledgments}

This research was supported by Abitibi-Bowater and the Research Institute for Agri-Environment (IRDA). Special thanks are extended to Michel Lemieux, Raynald Royer and Michel Noël for their assistance in plot maintenance and data collection.

\section{References}

1. N'Dayegamiye, A. Soil properties and crop yields in response to mixed paper mill sludges, dairy cattle manure, and inorganic fertilizer application. Agron. J. 2009, 101, 826-835.

2. Canali, S.; Ciaccia, C.; Tittarelli, F. Soil Fertility Management in Organic Potato: The Role of Green Manure and Amendment Applications. In Sustainable Potato Production: Global Case Studies; He, Z., Larkin, R., Honeycutt, W., Eds.; Springer: Heidelberg, The Netherlands, 2012; pp. 453-469.

3. N'Dayegamiye, A. Mixed paper mill sludges effects on corn yield, nitrogen efficiency and soil properties. Agron. J. 2006, 98, 1471-1478.

4. Ojala, J.C.; Stark, J.C.; Kleinkopf, G.E. Influence of irrigation and nitrogen management on potato yield and quality. Am. Potato J. 1990, 67, 29-44.

5. Porter, G.A.; Sisson, J.A. Response of Russet Burbank and Shepody potatoes to nitrogen fertilizer in two cropping systems. Am. Potato J. 1991, 68, 425-443.

6. Klausner, S.D.; Kanneganti, V.R.; Bouldin, D.R. An approach for estimating a decay series for organic nitrogen in animal manure. Agron. J. 1994, 86, 897-903.

7. Dahlin, S.; Kirchmann, H.; Käterer, T.; Gunnarsson, S.; Bergström, L. Possibilities for improving nitrogen use from organic materials in agricultural cropping systems. Ambio 2005, 34, 288-295.

8. Palm, C.A.; Sanchez, P.A. Nitrogen release from the leaves of some tropical legumes as affected by their lignin and polyphenolic contents. Soil Biol. Biochem. 1991, 23, 83-88.

9. Chadwick, D.R.; John, F.; Pain, B.F.; Chambers, B.J.; Williams, J. Plant uptake of nitrogen from the organic nitrogen fraction of animal manures: A laboratory experiment. J. Agric. Sci. 2000, 134, $159-168$.

10. Berry, P.M.; Sylvester-Bradley, R.; Philipps, L.; Hatch, D.J.; Cuttle, S.P.; Rayns, F.W.; Gosling, P. Is the productivity of organic farms restricted by the supply of available nitrogen. Soil Use Manag. 2002, 18, 248-255.

11. Douglas, B.F.; Magdoff, F.R. An evaluation of nitrogen mineralization indices for organic residues. J. Environ. Qual. 1991, 20, 368-372.

12. Loecke, D.; Liebman, M.; Cambardella, C.A.; Richard, T.L. Corn response to composting and time of application of solid swine manure. Agron. J. 2004, 96, 214-223.

13. Hansen, E.M.; Thomsen, I.K.; Hansen, M.N. Optimizing farmyard manure utilization by varying the application time and tillage strategy. Soil Use Manag. 2004, 20, 173-177.

14. Mitsch, W.J.; Day, J.W.; Gillian, J.W.; Hey, D.L.; Randall, G.W.; Wang, N. Reducing nitrogen loading to the Gulf of Mexico from the Mississipi River Basis: Strategies to counter a persistent ecological problem. Bioscience 2001, 51, 373-388. 
15. Magdoff, F. Understanding the Magdoff pre-sidedress nitrate test for corn. J. Prod. Agric. 1991, 4, 297-305.

16. Thomsen, I.K. Crop $\mathrm{N}$ utilization and leaching losses by time and method of application of farmyard manure. Eur. J. Agron. 2005, 22, 1-9.

17. Tran, T.S.; Giroux, M. Fertilisation azotée $\left({ }^{15} \mathrm{~N}\right)$ de la pomme de terre de primeur (Solanum tuberosum) selon les dates de récoltes. Agrosol 1991, 4, 20-29.

18. Olanya, O.M.; Lambert, D.H.; Porter, G.A. Effects of pest and soil management systems on potato diseases. Am. J. Potato Res. 2006, 83, 397-408.

19. Darby, H.M.; Stone, A.G; Dick, R.P. Compost and manure mediated impacts on soil borne pathogens and soil quality. Soil Sci. Am. J. 2006, 70, 347-358.

20. Hoitink, H.A.J.; Fahy, P.C. Basis for the control of soil borne plant pathogens with compost. Annu. Rev. Phytopathol. 1986, 24, 93-114.

21. Sturz, A.V.; Carter, M.R.; Johnston, H.W. A review of plant disease, pathogen interactions and microbial antagonism under conservation tillage in temperate humid agriculture. Soil Tillage Res. 1997, 41, 169-189.

22. Conn, K.L.; Lazarovits, G. Impact of animal manures on verticillium wilt, potato scab, and soil microbial populations. Can. J. Plant Pathol. 1999, 21, 81-92.

23. Lazarovits, G.; Conn, K.L.; Abbasi, P.A.; Soltani, N.; Kelly, W.; McMillan, E.; Peters, R.D.; Drake, K.A. Reduction of potato tuber diseases with organic soil amendments in two Prince Edward Island fields. Can. J. Plant Pathol. 2008, 30, 37-45.

24. Richard, J.E. Chemical Characterization of Plant Tissue. In Soil Sampling and Methods of Analysis; Carter, M.R., Ed.; Lewis Publisher: Boca Raton, FL, USA, 2001; pp. 115-139.

25. Allison, L.E.; Bollen, W.B.; Moodie, C.D. Total Carbon. In Methods of Soil Analysis; Black, C.A., Ed.; American Society of Agronomy: Madison, WI, USA, 1965; pp. 1346-1365.

26. Bremner, J.M.; Mulvaney, C.S. Total Nitrogen. In Methods of Soil Analysis; Page, A.L., Miller, R.H., Keeney, D.R., Eds.; American Society of Agronomy: Madison, WI, USA, 1982; pp. 595-622.

27. Mehlich, A. Mehlich 3 soil test extractant: A modification of Mehlich 2 extractant. Commun. Soil Sci. Plant Anal. 1984, 15, 1409-1416.

28. Gee, G.W.; Bauder, J.W. Particle Size Analysis. In Methods of Soil Analysis; Klute, A., Ed.; American Society of Agronomy: Madison, WI, USA, 1986; pp. 383-411.

29. Zvomuya, F.; Rosen, C.J.; Russelle, M.P.; Gupta, S.C. Nitrate leaching and nitrogen recovery following application of polyolefin-coated urea to potato. J. Environ. Qual. 2003, 32, 480-489.

30. SAS Institute SAS online Doc, version 2; SAS Institute Inc.: Carry, NC, USA, 2002.

31. MacLeod, J.A.; Sanderson, J.B.; Henry, R. Potato yield response to N as influenced by time of application of compost. Agric. Agri-Food Can. Agdex 1996, 161, 537.

32. Vagstad, N.; Broch-Due, A.; Lymgstad, I. Direct and residual effects of pulp and paper mill sludge on crop yield and soil mineral. Soil Use Manag. 2001, 17, 173-178.

33. Sommer, S.G. Effect of composting on nutrient loss and nitrogen availability of cattle deep litter. Eur. J. Agron. 2001, 14, 123-133. 
34. Gutser, R.; Ebertseder, T.; Weber, A.; Schram, M.; Schmidhalter, U. Short-term and residual availability of nitrogen after long-term application of organic fertilizers on arable land. J. Plant Nutr. Soil Sci. 2005, 168, 439-446.

35. Lapwood, D.H.; Hering, T.F. Infection of potato tubers by common scab (Streptomyces scabies) during brief periods when soil is drying. Eur. Potato J. 1968, 11, 177-197.

36. Lapwood, D.H.; Wellings, L.W.; Hawkins, J.H. Irrigation as a practical mean to control potato common scab (Streptomyces scabies): Final experiment and conclusions. Plant Pathol. 1973, 22, $35-41$.

(C) 2013 by the authors; licensee MDPI, Basel, Switzerland. This article is an open access article distributed under the terms and conditions of the Creative Commons Attribution license (http://creativecommons.org/licenses/by/3.0/). 